\title{
Alternatives to Subcutaneous Immunotherapy for Allergic Rhinitis
}

\author{
Tetsuya Terada *(1) and Ryo Kawata
}

Citation: Terada, T.; Kawata, R.

Alternatives to Subcutaneous

Immunotherapy for Allergic Rhinitis.

Allergies 2022, 2, 23-32. https://

doi.org/10.3390/allergies2010003

Academic Editor:

Emmanuel Prokopakis

Received: 15 December 2021

Accepted: 21 February 2022

Published: 24 February 2022

Publisher's Note: MDPI stays neutral with regard to jurisdictional claims in published maps and institutional affiliations.

Copyright: () 2022 by the authors. Licensee MDPI, Basel, Switzerland. This article is an open access article distributed under the terms and conditions of the Creative Commons Attribution (CC BY) license (https:// creativecommons.org/licenses/by/ $4.0 /)$.

\author{
Department of Otorhinolaryngology, Osaka Medical and Pharmaceutical University, Takatsuki 569-8686, Japan; \\ ryo.kawata@ompu.ac.jp \\ * Correspondence: tetsuya.terada@ompu.ac.jp; Tel.: +81-7-2683-1221
}

\begin{abstract}
Allergic rhinitis (AR) is an important public health issue worldwide due to its increasing prevalence and impact on quality of life, school performance, and work productivity. Subcutaneous immunotherapy (SCIT) is used to treat AR and involves repeated injections of allergen extracts. SCIT is used for cases of severe AR with symptoms that are not adequately controlled by medication, when the side effects of medication limit treatment options, or where the aim is to cure rather than symptomatically treat. Although SCIT is effective, it is not necessarily curative. Furthermore, there is also a low but present risk of systemic allergic reactions, with systemic side effects occurring in less than $0-1 \%$ of treated patients. Sublingual immunotherapy (SLIT) has emerged as an effective and safe alternative to SCIT. SCIT and SLIT are the only immunotherapies currently available for AR. In addition to sublingual administration as an alternative to SCIT, other routes of antigen administration have been attempted with the goal of increasing safety while maintaining efficacy. This review discusses the efficacies of SCIT and SLIT, their mechanisms, the utility of intralymphatic immunotherapy (ILIT) as an alternative route of antigen administration, and the potential for immunotherapy using other routes of antigen administration.
\end{abstract}

Keywords: subcutaneous immunotherapy; sublingual immunotherapy; intralymphatic immunotherapy; allergic rhinitis; IgE; IgG4

\section{Introduction}

The parenteral administration of allergens as immunotherapy has been used for nearly a century as a disease-modifying therapy for allergic respiratory diseases [1,2]. In contrast to pharmacotherapy for allergic rhinitis (AR), which focuses on symptom control, the main aim of allergen-specific immunotherapy (SIT) is to modify the immune system and cure AR. SIT also effectively reduces symptoms and the need for medication over time and prevents sensitization to new allergens and the development of asthma [3,4].

Subcutaneous administration was the sole effective route for administering allergens for more than 100 years [5].

During this time, extensive efforts were made to improve and standardize the quality of allergen extracts, with subcutaneous immunotherapy (SCIT) ultimately being established as a safer and more effective treatment $[4,6]$. Sublingual administration was developed in the 1990s and has become the standard route of administration. A drop of a solution is placed under the tongue and kept in the mouth for two minutes before being swallowed [7].

Other routes of administration were also considered, and various teams have investigated the efficacy of intranasal administration, with some reports [8-10]. Oral administration has failed to demonstrate efficacy against respiratory allergies but is expected to be effective against food allergies [11]. A previous study on grass pollen reported that transdermal administration using a patch test (applied to the skin for one to several days) reduced the symptoms of AR [12]. Intralymphatic allergen injections have recently been 
investigated as a promising new route of administration [13]. Intralymphatic immunotherapy (ILIT), consisting of three injections into the lymph nodes, has reduced the symptoms of rhinoconjunctivitis in humans [14].

Three main approaches are employed to increase the efficacy and safety of antigenspecific immunotherapy: improving the antigen administered, developing a route of antigen administration, and improving the administration schedule [13].

This review focuses on the effects of improving the route of antigen administration on the efficacy of antigen-specific immunotherapy.

\section{Immunotherapy for AR: SCIT, SLIT, ILIT}

\subsection{SCIT}

SCIT is used to treat AR and involves repeated injections of allergen extracts. SCIT is used for cases of severe AR with symptoms that are not adequately controlled by medication, when the side effects of medication limit treatment options, or where the aim is to cure rather than symptomatically treat.

Although SCIT is effective, it is not necessarily curative. Furthermore, there is also a low but present risk of systemic allergic reactions, with systemic side effects occurring in less than $0-1 \%$ of treated patients [15]. It also needs to be administered under the supervision of a skilled physician who is trained to adjust the immunotherapy dosage, and patients need to be observed for 15 to $30 \mathrm{~min}$ after the injection due to the risk of serious systemic side effects [16].

The efficacy of SCIT for seasonal allergic rhinitis (SAR), which was confirmed by greater reductions in seasonal symptoms and rescue medication than with a placebo, was recently reported [3]. The findings of a large, randomized trial also supported the dose-dependent efficacy of SCIT for SAR [17].

Since the effects of SCIT and regularly administered medication have not yet been directly compared in detail, future studies are warranted. Limited evidence is currently available to support the efficacy of the subcutaneous administration of allergens for perennial AR and there is a paucity of up-to-date systematic reviews or meta-ensembles. There are also no systematic reviews or meta-analyses. However, individual studies have demonstrated efficacy. Varney et al. [18] reported a 58\% reduction in symptoms and a $20 \%$ reduction in the use of rescue medication with house dust mite (HDM) immunotherapy despite a large placebo effect. In a randomized controlled trial (RCT) on the efficacy of HDM immunotherapy for rhinitis, significant decreases were observed in a clinical index derived from symptom and drug scores, visual analog scores, the results of nasal challenge and skin prick tests, and also in each parameter examined [19].

\subsection{SLIT}

SLIT is effective for adults and children, and monitoring by physicians is only required for the first dose [20,21]. SLIT is considered to be safer than SCIT because side effects are generally confined to the upper respiratory tract and gastrointestinal tract [22]. The clinical and immunological effects of SLIT, similar to those of SCIT, have been suggested to persist after 3 years of continuous use [23].

Furthermore, localized changes occur in the oral cavity that are specific to SLIT [24].

Although further studies are needed on the persistence and concordance of SLIT, particularly in children [23], we consider it to be an effective treatment and preventive method for asthma $[25,26]$.

\subsection{ILIT}

Intralymphatic immunotherapy (ILIT) for some allergens, such as cat dander and pollen, was found to be effective for AR [14,27-30]. ILIT induces tolerance to a specific allergen more rapidly than SCIT and SLIT after only three injections of allergen extracts and does not induce serious adverse effects. Antigens administered into the lymph nodes may be efficiently delivered to antigen-presenting cells, followed by the activation of $\mathrm{T}$ 
and B cells. Therefore, ILIT may be advantageous because only a few injections of a small amount of an allergen extract are needed to achieve clinical effectiveness.

We previously demonstrated the clinical effectiveness of ILIT against Japanese cedar pollinosis and investigated whether the clinical effectiveness of ILIT, in which pollen extracts were intralymphatically injected three times before the pollen season, persisted in two subsequent pollen seasons [31].

SCIT and SLIT are the only immunotherapies currently available for AR. Although there are many unanswered questions regarding the underlying mechanisms of action, antigen epitopes fragmented by antigen-presenting cells may be taken up by the affiliated lymph nodes, leading to an immune non-response. However, in comparison with the amount of antigen administered subcutaneously or sublingually, the amount of antigen taken up by the lymph nodes with ILIT appears to be markedly smaller (Table 1). The direct administration of an antigen into the lymph nodes may induce immune tolerance with a very small amount of the antigen and this has been the focus of research in a number of clinical studies.

Table 1. Comparison among SCIT, SLIT, ILIT.

\begin{tabular}{|c|c|c|c|}
\hline & SCIT & SLIT & ILIT \\
\hline Administration & Subcutaneous & Sublingual & $\begin{array}{l}\text { Injection to lymph } \\
\text { node }\end{array}$ \\
\hline Pre treatment & $\begin{array}{l}\text { Sometimes } \\
\text { (medication) }\end{array}$ & $\begin{array}{l}\text { Sometimes } \\
\text { (medication) }\end{array}$ & None \\
\hline $\begin{array}{l}\text { Amount of antigen } \\
\text { administered }\end{array}$ & moderate & high & small \\
\hline AE (systemic) & rare but sometimes & a few report & None \\
\hline
\end{tabular}

\subsection{Pharmacotherapy and Immunotherapy}

The basic treatment of AR is considered to be antigen avoidance and drug therapy, with non-sedating antihistamines and intranasal corticosteroids being the mainstay of pharmacotherapy [32-34]. Inadequate responses to these drug treatments are often attributed to poor compliance. Immunotherapy may be considered when antigen avoidance, medication, and intranasal corticosteroids do not effectively control symptoms. Since the induction phase of AR cannot be altered by pharmacological treatment, medication must be repeated based on the symptoms being presented [24,32]. In contrast to pharmacotherapy, immunotherapy is regarded as a curative treatment that alters the induction phase. Immunotherapy, whether subcutaneous or sublingual, has the potential to cure the disease, in contrast to pharmacotherapy, and its efficacy has been reported in a number of RCTs [35,36], which may be maintained for 2-3 years after the completion of immunotherapy [24,37-41].

The criteria for selecting immunotherapy are inadequate responses to pharmacotherapy and the goal of a cure. In cases in which pharmacotherapy is inadequate, immunotherapy may be applied in addition to pharmacotherapy, which switches the main focus of treatment from pharmacotherapy to immunotherapy, with drug administration as a rescue.

The efficacy of immunotherapy differs between SAR and perennial AR, with SCIT being more effective for the former and less effective for the latter $[4,42]$. SLIT is also highly effective for SAR; however, evidence to support its efficacy for perennial AR, particularly in children, is currently limited [43].

\subsection{Adverse Events of Immunotherapy}

Antigen-specific immunotherapy involves altering the route of administration of an antigen that induces nasal allergic symptoms and administering it subcutaneously or sublingually such that allergic reactions are induced locally. These local allergic reactions are of little importance as side effects because subcutaneous administration merely causes 
redness and itching of the skin and sublingual administration results in itching of the mucous membrane of the oral floor under the tongue.

In SLIT, the reported frequency of adverse reactions widely varies. Some studies identified mild local itching as an adverse reaction, whereas others did not recognize minor local symptoms as an adverse reaction. Although there is currently no information on fatal adverse reactions associated with SLIT, it is safer than SCIT [43].

\subsection{Frequency of Adverse Reactions}

Among antigen-specific immunotherapies, the frequency of adverse reactions differs between SCIT and SLIT. The incidence of systemic adverse reactions to SCIT was previously reported to be $0.025 \%$ in terms of the number of inoculations [15], while that of serious anaphylactic reactions to SCIT for SAR was 5.4 per million injections $(0.0005 \%)$, with an increased incidence $(46 \%)$ during the period of high pollen counts [44,45]. Anaphylactic reactions due to SLIT have been reported in 11 cases, indicating that anaphylaxis occurred once in approximately 100 million injections, and no fatal cases have been reported to date [45]. In a study on systemic reactions in 66 trials with 4378 patients receiving approximately 1,181,000 doses of SLIT, systemic adverse reactions were detected for 169 out of 314,959 doses $(0.056 \%)$, while severe systemic reactions occurred for 14 out of $1,181,000$ doses $(0.0014 \%)$ [46]. The most common systemic reaction was asthma, which required hospitalization in one case [46].

Senti et al. [14] reported that there were significantly fewer adverse reactions with ILIT than with SCIT, with 18 mild grade 1 or 2 adverse reactions and 2 cases of asthmatic reactions requiring treatment in a medical facility during the first 4 months. In contrast to SCIT, there were 18 mild adverse reactions and 2 asthmatic reactions requiring institutional care in the first 4 months, and ILIT only caused 6 mild adverse reactions and no systemic anaphylactic reactions requiring hospitalization. Due to differences in the number of antigens administered within the first four months, the two groups were not comparable; however, the lack of anaphylactic reactions attributable to antigen administration into the lymph nodes is noteworthy.

The causes of anaphylaxis may be associated with prior systemic reactions, concomitant immunodeficiency, poor compliance with treatment, re-administration after treatment interruption, severe or poorly controlled asthma, a high pollen count, the use of nonstandardized extracts, and the lack of dose escalation periods.

\subsection{Types of Adverse Reactions}

Adverse reactions to antigen-specific immunotherapy may be broadly divided into excessive local reactions and systemic adverse reactions. In SLIT, oral symptoms, such as oral itching, swelling of the lips, and pharyngeal irritation, are common local reactions [47]. This corresponds to redness and swelling at the injection site in SCIT. Systemic adverse reactions to SLIT are less common but are mostly asthma attacks or gastrointestinal symptoms. Other severe systemic reactions include abdominal pain, vomiting, edema of the palate, and urticaria that persists for $48 \mathrm{~h}[46,47]$.

\subsection{Effects and Adverse Reactions of Immunotherapy}

A more detailed understanding of the balance between the efficacy of SCIT and SLIT is needed to control symptoms and the frequency and severity of side effects. A comparison of a large double-blind study on SCIT by Frew et al. and a double-blind study on SLIT by Dahl et al., both of which had similar methodologies and sample sizes, showed the similar efficacies of SCIT and SLIT for reducing nasal and ocular symptoms (26 to 36\% reduction in symptoms) $[17,37,38]$. The adverse effects of SLIT included oral pruritus in $46 \%$ and lip swelling in $18 \%$ of patients, with $4 \%$ of 634 patients withdrawing from the study, while those of SCIT included grade 2 systemic adverse reactions in $17.2 \%$ and grade 3 systemic adverse reactions in $4.4 \%$. Comparisons of the symptom suppressive effects of SCIT and SLIT in the literature provided inconclusive findings, with some studies suggesting that 
SCIT was more effective $[48,49]$ and others showing equivalent scores of $-0.92(p<0.0001)$ for SCIT and -0.40 ( $p=0.0008)$ for SLIT in the form of sublingual tablets, concluding that SCIT is more effective. A large-scale direct comparison of the efficacy and incidence of side effects between SCIT and SLIT is warranted in the future.

\subsection{Adherence}

SCIT requires frequent visits during the dosage increase period, whereas 12 visits per year, namely once a month, are sufficient for maintenance therapy. Six visits per year are necessary for SLIT prescribed for two months. The number of antigen doses for SCIT is 12 per year, whereas SLIT requires daily dosing 365 days per year. SCIT also requires more frequent hospital visits and may lead to poorer adherence. However, patients may decide whether daily dosing in SLIT or 12 visits and subcutaneous administration in SCIT is more suitable.

Adherence to SLIT with fewer hospital visits may not always be the better option. In a study performed in the Netherlands [50], the adherence rates of SCIT and SLIT at 1 and 3 years were 80 and $23 \%$ and 38 and $7 \%$, respectively, with significantly higher adherence rates being observed for SCIT. The social background and preferences of patients clearly play an important role in retention rates.

\subsection{Efficacy and Safety of SCIT versus SLIT}

Durham et al. [51] demonstrated that SCIT and SLIT both effectively reduced symptoms and the need for rescue medication in patients with AR, with these effects being stronger for SAR than for perennial AR and in adults than in children. SLIT tablets were also found to be effective in patients with perennial AR caused by HDM [7,52-55].

Three years of treatment with both SCIT and SLIT has been shown to provide longterm clinical benefits for at least two years after the discontinuation of treatment. The findings of indirect comparisons of the relative efficacy of SCIT and SLIT are controversial, with two studies favoring SCIT [49,50] and a third finding no difference [56].

In terms of tolerability and safety, SLIT was shown to be superior to SCIT, albeit in an indirect comparison [7,52-55]. SCIT may cause anaphylaxis and, thus, requires close observation, whereas SLIT is more tolerable than SCIT based on information in a large database of clinical trials and post-marketing surveillance. A large database of clinical trials and post-marketing surveillance showed that systemic side effects were rare, anaphylaxis was extremely rare, and SLIT may be safely self-administered [7,52-55]. Local side effects, such as itching and swelling of the mouth, are common but generally mild and resolve without treatment; therefore, withdrawal due to local side effects is rare.

In contrast to SLIT, for which the maintenance dose is fixed, the maintenance dose for SCIT may be set according to the individual thresholds of patients. An increase in the interval between the maintenance doses of the antigen from once a month to once a week just before the pollen season may increase symptom suppressive effects during the pollen season (unpublished data). The ability to tailor the intensity of treatment to individual patients may be an important feature of SCIT that differentiates it from SLIT.

\subsection{Comparison of ILIT with SCIT}

The efficacy and safety of three ILIT have been investigated in a double-blind, randomized study using a group of patients treated with SCIT for more than three years as controls [14]. Senti et al. [14] randomized 99 patients to receive SCIT for more than 3 years and with 54 subcutaneous injections (total antigen dose: 4,031,540 SQ-U) and 66 patients to receive a total of 3 doses of intralymphatic injections (3000 SQ-U) over an 8-week period. Efficacy and changes in antibody titers were assessed at the start of treatment and after 4 months, 1 year, and 3 years. 


\subsection{Movement of an Antigen Administered Subcutaneously or into the Lymph Nodes}

When isotope-labeled IgG antibodies were subcutaneously administered into the right lymph nodes and to the left side of the abdomen and examined $24 \mathrm{~h}$ later, the antigen administered directly into the lymph nodes remained in the lymph nodes and also accumulated in the surrounding lymph nodes. In contrast, the antigen administered subcutaneously dispersed, with only a very small amount of uptake in the regional lymph nodes [28].

The mechanisms by which the administered antigen is utilized by $\mathrm{T}$ and $\mathrm{B}$ lymphocytes in the lymph nodes as a source of immunity have not yet been elucidated; however, the direct administration of the antigen into the lymph nodes has been shown to achieve long-lasting, highly concentrated antigen retention in the lymph nodes.

Regarding adverse reactions, there were no cases of swelling of antigen-treated lymph nodes [31]. In a few cases, redness and itching were observed at the injection site; however, this appeared to be a subcutaneous reaction to the small amount of antigen that leaked into the skin. Anaphylactic reactions are not expected to occur in the lymph nodes because they are essentially free of mast cells and poorly vascularized.

\section{Mechanism of Action of Immunotherapy}

Although SCIT and SLIT both specifically suppress allergic reactions to the antigen administered, their mechanisms of action remain unclear. The route of administration of the antigen differs; however, the antigen itself is essentially the same, and the mechanisms of action of SLIT and SCIT appear to be similar in terms of the induction of immune tolerance in the affiliated lymph nodes.

\subsection{Induction of Regulatory T Cells}

The induction of regulatory $\mathrm{T}$ cells and their production of inhibitory cytokines, such as IL-10 and TGF-b, which suppress allergic inflammation and increase the IgG4/IgE ratio, are considered to be the main mechanisms of action of immunotherapy [57]. There are several subsets of regulatory T cells, including Foxp3-positive T cells, Foxp3-negative Tr1 cells, and Th3 cells, and antigen-specific immunotherapy is considered to mainly induce Foxp3-positive T cells and Foxp3-negative Tr1 cells. In an autologous study on SCIT, IL-10producing Foxp3-negative Tr1 cells were found to be significantly induced [58], while in a study on SLIT, Foxp3-positive T cells and Foxp3-negative Tr1 cell numbers both increased, and the VAS score for symptom improvement positively correlated with the number of Foxp3-positive T cells [59]. Furthermore, a positive correlation was noted between the VAS score for symptom improvement and the number of Foxp3-positive T cells [59].

\subsection{Increase in IgG4 Antibodies}

Although antigen-specific immunotherapy increases antigen-specific IgG4 antibodies, their involvement in the mechanism of action of this treatment remains unclear. Matsuda et al. [58] indicated that SCIT resulted in a significant increase in antigen-specific IgG4 antibodies 1 year after treatment, whereas SLIT did not. However, a significant increase was observed in antigen-specific IgG4 antibodies 3 years after SLIT, although it was not as large as that with SCIT [58].

IgG antibodies have been suggested to function as blocking antibodies that inhibit the binding of the antigen to IgE antibodies, but this has not been shown to correlate with symptom suppression. The effects of antigen-specific immunotherapy on B cells include the promotion of IgG4 antibody production and the induction of IL-10-producing regulatory B cells [58].

The co-binding of FceRI, a high affinity IgE receptor, with FcgRIIb, a low affinity IgG receptor, has been shown to inhibit degranulation reactions in mast cells and basophils [60-64]. The chimeric antibody, gamma-Fel d1, is a genetically engineered antibody that combines Fel d1, a major antigen responsible for cat allergy, with the Fc site of human IgG RIIb receptors and suppresses effector functions by inhibiting signal transduction $[64,65]$. 
The IgG4 antibody produced by antigen-specific immunotherapy may form an antigenantibody complex with the antigen, which then binds to the IgE antibody on FceRI, while the IgG4 antibody in the complex binds to FcgRIlb, thereby suppressing the chemical mediator release signal from IgE-FceRI in mast cells and basophils.

However, it currently remains unclear whether the IgG4 antibody, which is increased by antigen-specific immunotherapy, suppresses effector function in a dose-dependent manner or through co-binding to FceRI and FcgRIIb by antigen-antibody complexes.

Antigen-specific immunotherapy has also been shown to induce IL-10-producing regulatory B cells [66]. We previously reported that SCIT for cedar pollinosis significantly induced CD19-positive IL-10-producing B cells [58].

\subsection{Production of $I L-10$}

IL-10 is efficiently produced by regulatory $\mathrm{T}$ cells and regulatory B cells induced by antigen-specific immunotherapy, and IL-10 is considered to suppress various allergic reactions and induce the production of the IgG4 antibody from B cells.

IL-10-producing regulatory cells are crucially involved in the clinical therapeutic mechanisms underlying immunotherapy. A previous study on SCIT using HDM extract in patients allergic to HDM showed that SCIT induced reductions in the proliferation of peripheral blood mononuclear cells (PBMC) and the production of IFN- $\gamma$, IL5, and IL13 by PBMC stimulated with Der $\mathrm{p} 1$ (a major allergen of HDM) 70 days after treatment from the levels measured prior to treatment initiation [67].

IL-10 production levels after 3 years of SLIT were found to correlate with the amelioration of clinical symptoms assessed using forced expiratory flow between 25 and $75 \%$ (FEF25-75) [68].

\section{Alternative Routes of Immunotherapy}

The use of other antigen administration routes beside sublingual administration as an alternative to SCIT has been attempted, with the goal of increasing safety while maintaining efficacy. Two clinical trials showed that the inhalation route was effective but limited by bronchospasms [69,70]. Although the oral route was also examined, the findings obtained were not promising [14,71,72]. In contrast, several well-designed clinical trials demonstrated the effectiveness of nasal immunotherapy [73]. Although encouraging, intranasal administration is less acceptable to patients, mainly because of persistent local side effects, such as sneezing and a runny nose, which require topical nasal premedication, and its therapeutic modalities are limited. Intranasal immunotherapy has been limited to AR and its long-term efficacy and preventive effects currently remain unknown. The transdermal use of allergen-containing patches has generated considerable interest; however, data are still preliminary [12].

Author Contributions: Conceptualization, T.T. and R.K.; original draft preparation, T.T.; review and editing; T.T. and R.K.; review and editing, R.K. All authors have read and agreed to the published version of the manuscript.

Funding: This research received no external funding.

Institutional Review Board Statement: Not applicable.

Informed Consent Statement: Not applicable.

Data Availability Statement: All data generated or analyzed during this study are included in this published article.

Conflicts of Interest: The authors declare no conflict of interest.

\section{References}

1. Noon, L. Prophylactic inoculation against hay fever. Lancet 1911, 1, 1572-1573. [CrossRef]

2. Freeman, J. Vaccination against hay fever: Report of results during the first three years. Lancet 1914, 1, 1178-1180. [CrossRef]

3. Calderon, M.A. Meta-analyses of specific immunotherapy trials. Drugs Today 2008, 44 (Suppl. SB), 31-34. 
4. Calderon, M.A.; Alves, B.; Jacobson, M.; Hurwitz, B.; Sheikh, A.; Durham, S. Allergen injection immunotherapy for seasonal allergic rhinitis. Cochrane Database Syst. Rev. 2007, 1, CD001936. [CrossRef]

5. Mailhol, C.; Didier, A. Specific immunotherapy in grass pollen allergy. Hum. Vaccin Immunother. 2012, 8, 1544-1547. [CrossRef]

6. Jutel, M.; Akdis, C.A. Immunological mechanisms of allergen-specific immunotherapy. Allergy 2011, 66, 725-732. [CrossRef]

7. Okamoto, Y.; Okubo, K.; Yonekura, S.; Hashiguchi, K.; Goto, M.; Otsuka, T.; Murata, T.; Nakao, Y.; Kanazawa, C.; Nagakura, H.; et al. Efficacy and safety of sublingual immunotherapy for two seasons in patients with Japanese cedar pollinosis. Int. Arch. Allergy Immunol. 2015, 166, 177-188. [CrossRef]

8. Marcucci, F.; Sensi, L.G.; Caffarelli, C.; Cavagni, G.; Bernardini, R.; Tiri, A.; Riva, G.; Novembre, E. Low-dose local nasal immunotherapy in children with perennial allergic rhinitis due to Dermatophagoides. Allergy 2002, 57, 23-28.

9. Ascione, E.; De Lucia, A.; Imperiali, M.; Varricchio, A.; Motta, G. Nasal application of Immunotherapy. Chem. Immunol. Allergy 2003, 82, 89-98. Available online: http:/ / www.ncbi.nlm.nihgov/pubmed/12947995 (accessed on 15 December 2021 ).

10. Tsai, J.J.; Liao, E.C.; Tsai, F.H.; Hsieh, C.C.; Lee, M.F. The effect of local nasal immunotherapy in allergic rhinitis: Using strips of the allergen Dermatophagoides pteronyssinus. J. Asthma 2009, 46, 165-170. Available online: http://www.ncbi.nlmnih.gov/ pubmed/19253124 (accessed on 15 December 2021). [CrossRef]

11. Burks, A.W.; Laubach, S.; Jones, S.M. Oral tolerance, food allergy, and immunotherapy: Implications for future treatment. J. Allergy Clin. Immunol. 2008, 121, 1344-1350. [CrossRef]

12. Senti, G.; Graf, N.; Haug, S.; Rüedi, N.; von Moos, S.; Sonderegger, T.; Johansen, P.; Kündig, T.M. Epicutaneous allergen administration as a novel method of allergen-specific immunotherapy. J. Allergy Clin. Immunol. 2009, 124,997-1002. [CrossRef] [PubMed]

13. Martínez-Gómez, J.M.; Johansen, P.; Erdmann, I.; Senti, G.; Crameri, R.; Kündig, T.M. Intralymphatic injections as a new administration route for allergen-specific immunotherapy. Int. Arch. Allergy Immunol. 2009, 150, 59-65. [PubMed]

14. Senti, G.; Prinz Vavricka, B.M.; Erdmann, I.; Diaz, M.I.; Markus, R.; McCormack, S.J.; Simard, J.J.; Wüthrich, B.; Crameri, R. Graf, N.; et al. Intralymphatic allergen administration renders specific immunotherapy faster and safer: A randomized controlled trial. Proc. Natl. Acad. Sci. USA 2008, 105, 17908-17912. [CrossRef] [PubMed]

15. Roy, S.R.; Sigmon, J.R.; Olivier, J.; Moffitt, J.E.; Brown, D.A.; Marshall, G.D. Increased frequency of large local reactions among systemic reactors during subcutaneous allergen immunotherapy. Ann. Allergy Asthma Immunol. 2007, 99, 82-86. [CrossRef]

16. Roberts, G.; Pfaar, O.; Akdis, C.A.; Ansotegui, I.J.; Durham, S.R.; Gerth van Wijk, R.; Halken, S.; Larenas-Linnemann, D.; Pawankar, R.; Pitsios, C.; et al. EAACI Guidelines on Allergen Immunotherapy: Allergic rhinoconjunctivitis. Allergy 2018, 73, 765-798. [CrossRef]

17. Frew, A.J.; Powell, R.J.; Corrigan, C.J.; Durham, S.R.; UK Immunotherapy Study Group. Efficacy and safety of specific immunotherapy with SQ allergen extract in treatment-resistant seasonal allergic rhinoconjunctivitis. J. Allergy Clin. Immunol. 2006, 117, 319-325. [CrossRef]

18. Varney, V.A.; Tabbah, K.; Mavroleon, G.; Frew, A.J. Usefulness of specific immunotherapy in patients with severe perennial allergic rhinitis induced by house dust mite: A double-blind, randomized, placebo-controlled trial. Clin. Exp. Allergy 2003, 33, 1076-1082. [CrossRef]

19. Ewan, P.W.; Alexander, M.M.; Snape, C.; Ind, P.W.; Agrell, B.; Dreborg, S. Effective hyposensitization in allergic rhinitis using a potent partially purified extract of house dust mite. Clin. Allergy 1988, 18, 501-508. [CrossRef]

20. Canonica, G.W.; Bousquet, J.; Casale, T.; Lockey, R.F.; Baena-Cagnani, C.E.; Pawankar, R.; Potter, P.C. Sub-lingual immunotherapy: World Allergy Organization Position. Allergy 2009, 64 (Suppl. S91), 2009

21. Larenas-Linnemann, D. Sublingual immunotherapy in children: Complete and updated review supporting evidence of effect. Curr. Opin. Allergy Clin. Immunol. 2009, 9, 168-176. [CrossRef] [PubMed]

22. James, L.K.; Durham, S.R. Update on mechanisms of allergen injection immunotherapy. Clin. Exp. Allergy 2008, 38, 1074-1088. [CrossRef] [PubMed]

23. Scadding, G.W.; Shamji, M.H.; Jacobson, M.R.; Lee, D.I.; Wilson, D.; Lima, M.T.; Pitkin, L.; Pilette, C.; Nouri-Aria, K.; Durham, S.R. Sublingual grass pollen immunotherapy is associated with increases in sublingual Foxp3-expressing cells and elevated allergen-specific immunoglobulin G4, immunoglobulin A and serum inhibitory activity for immunoglobulin E-facilitated allergen binding to B cells. Clin. Exp. Allergy 2010, 40, 598-606. [PubMed]

24. Durham, S.R.; Emminger, W.; Kapp, A.; Colombo, G.; de Monchy, J.G.; Rak, S.; Scadding, G.K.; Andersen, J.S.; Riis, B.; Dahl, R. Long-term clinical efficacy in grass pollen-induced rhinoconjunctivitis after treatment with SQ-standardized grass allergy immunotherapy tablet. J. Allergy Clin. Immunol. 2010, 125, 131-138.e1. [CrossRef] [PubMed]

25. Kuo, C.H.; Wang, W.L.; Chu, Y.T.; Lee, M.S.; Hung, C.H. Sublingual immunotherapy in children: An updated review. Pediatr. Neonatol. 2009, 50, 44-49. [CrossRef]

26. Krouse, J.H. Sublingual immunotherapy for inhalant allergy: Cautious optimism. Otolaryngol. Head Neck Surg. 2009, 140, 622-624. [CrossRef]

27. Hylander, T.; Larsson, O.; Petersson-Westin, U.; Eriksson, M.; Kumlien Georén, S.; Winqvist, O.; Cardell, L.O. Intralymphatic immunotherapy of pollen-induced rhinoconjunctivitis: A double-blind placebo-controlled trial. Respir. Res. 2016, 17, 10. [CrossRef]

28. Senti, G.; Johansen, P.; Kündig, T.M. Intralymphatic immunotherapy. Curr. Opin. Allergy Clin. Immunol. 2009, 9, 537-543. [CrossRef] 
29. Senti, G.; Crameri, R.; Kuster, D.; Johansen, P.; Martinez-Gomez, J.M.; Graf, N.; Steiner, M.; Hothorn, L.A.; Grönlund, H.; Tivig, C.; et al. Intralymphatic immunotherapy for cat allergy induces tolerance after only 3 injections. J. Allergy Clin. Immunol. 2012, 129, 1290-1296. [CrossRef]

30. Hylander, T.; Latif, L.; Petersson-Westin, U.; Cardell, L.O. Intralymphatic allergen-specific immunotherapy: An effective and safe alternative treatment route for pollen-induced allergic rhinitis. J. Allergy Clin. Immunol. 2013, 131, 412-420. [CrossRef]

31. Terada, T.; Omura, S.; Kikuoka, Y.; Suzuki, M.; Inaka, Y.; Inui, T.; Matsuda, M.; Nabe, T.; Kawata, R. Sustained effects of intralymphatic pollen-specific immunotherapy on Japanese cedar pollinosis. Rhinology 2020, 58, 241-247. [CrossRef] [PubMed]

32. Bousquet, J.; Khaltaev, N.; Cruz, A.A.; Denburg, J.; Fokkens, W.J.; Togias, A.; Zuberbier, T.; Baena-Cagnani, C.E.; Canonica, G.W.; van Weel, C.; et al. Allergic Rhinitis and its Impact on Asthma (ARIA) 2008 update (in collaboration with the World Health Organization, GA(2)LEN and allergen). Allergy 2008, 63 (Suppl. S86), 8-160. [PubMed]

33. Wheatley, L.M.; Togias, A. Clinical practice. Allergic rhinitis. N. Engl. J. Med. 2015, 372, 456-463. [CrossRef] [PubMed]

34. Greiner, A.N.; Hellings, P.W.; Rotiroti, G.; Scadding, G.K. Allergic rhinitis. Lancet 2011, 378, 2112-2122. [CrossRef]

35. Durham, S.R.; Emminger, W.; Kapp, A.; de Monchy, J.G.; Rak, S.; Scadding, G.K.; Wurtzen, P.A.; Andersen, J.S.; Tholstrup, B.; Riis, B.; et al. SQ-standardized sublingual grass immunotherapy: Confirmation of disease modification 2 years after 3 years of treatment in a randomized trial. J. Allergy Clin. Immunol. 2012, 129, 717-725.e5. [CrossRef]

36. Durham, S.R.; Walker, S.M.; Varga, E.M.; Jacobson, M.R.; O’Brien, F.; Noble, W.; Till, S.J.; Hamid, Q.A.; Nouri-Aria, K.T. Long-term clinical efficacy of grass-pollen immunotherapy. N. Engl. J. Med. 1999, 341, 468-475. [CrossRef]

37. Dahl, R.; Kapp, A.; Colombo, G.; de Monchy, J.G.; Rak, S.; Emminger, W.; Rivas, M.F.; Ribel, M.; Durham, S.R. Efficacy and safety of sublingual immunotherapy with grass allergen tablets for seasonal allergic rhinoconjunctivitis. J. Allergy Clin. Immunol. 2006, 118, 434-440. [CrossRef]

38. Didier, A.; Worm, M.; Horak, F.; Sussman, G.; de Beaumont, O.; Le Gall, M.; Melac, M.; Malling, H.J. Sustained 3-year efficacy of pre- and coseasonal 5-grass-pollen sublingual immunotherapy tablets in patients with grass pollen-induced rhinoconjunctivitis. J. Allergy Clin. Immunol. 2011, 128, 559-566. [CrossRef]

39. Ott, H.; Sieber, J.; Brehler, R.; Fölster-Holst, R.; Kapp, A.; Klimek, L.; Pfaar, O.; Merk, H. Efficacy of grass pollen sublingual immunotherapy for three consecutive seasons and after cessation of treatment: The ECRIT study. Allergy 2009, 64, 1394-1401. [CrossRef]

40. Didier, A.; Malling, H.J.; Worm, M.; Horak, F.; Sussman, G.; Melac, M.; Soulié, S.; Zeldin, R.K. Post-treatment efficacy of discontinuous treatment with 300IR 5-grass pollen sublingual tablet in adults with grass pollen-induced allergic rhinoconjunctivitis. Clin. Exp. Allergy 2013, 43, 568-577. [CrossRef]

41. Didier, A.; Malling, H.J.; Worm, M.; Horak, F.; Sussman, G.L. Prolonged efficacy of the 300IR 5-grass pollen tablet up to 2 years after treatment cessation, as measured by a recommended daily combined score. Clin. Transl. Allergy 2015, 5, 12. [CrossRef] [PubMed]

42. Calderon, M.A.; Penagos, M.; Carr, V.A.; Lagos, M.; Garcia-Nunez, I.; Sheikh, A.; Durham, S.R. Allergen injection immunotherapy for perennial allergic rhinitis. Allergy 2013, 68, 643-644.

43. Calderon, M.A.; Casale, T.B.; Nelson, H.S.; Demoly, P. An evidence-based analysis of house dust mite allergen immunotherapy: A call for more rigorous clinical studies. J. Allergy Clin. Immunol. 2013, 132, 1322-1336. [CrossRef] [PubMed]

44. Amin, H.S.; Liss, G.M.; Bernstein, D.I. Evaluation of near-fatal reactions to allergen immunotherapy injections. J. Allergy Clin. Immunol. 2006, 117, 169-175. [CrossRef] [PubMed]

45. Wise, S.K.; Schlosser, R.J. Evidence-based practice: Sublingual immunotherapy for allergic rhinitis. Otolaryngol. Clin. N. Am. 2012, 45, 1045-1054. [CrossRef] [PubMed]

46. Cox, L.; Wallace, D. Specific allergy immunotherapy for allergic rhinitis: Subcutaneous and sublingual. Immunol. Allergy Clin. N. Am. 2011, 31, 561-599. [CrossRef]

47. Radulovic, S.; Calderon, M.A.; Wilson, D.; Durham, S. Sublingual immunotherapy for allergic rhinitis. Cochrane Database Syst. Rev. 2010, 12, CD002893. [CrossRef]

48. Dretzke, J.; Meadows, A.; Novielli, N.; Huissoon, A.; Fry-Smith, A.; Meads, C. Subcutaneous and sublingual immunotherapy for seasonal allergic rhinitis: A systematic review and indirect comparison. J. Allergy Clin. Immunol. 2013, 131, 1361-1366. [CrossRef]

49. Di Bona, D.; Plaia, A.; Leto-Barone, M.S.; La Piana, S.; Di Lorenzo, G. Efficacy of subcutaneous and sublingual immunotherapy with grass allergens for seasonal allergic rhinitis: A meta-analysis-based comparison. J. Allergy Clin. Immunol. 2012, 130, 1097-1107.e2. [CrossRef]

50. Kiel, M.A.; Röder, E.; Gerth van Wijk, R.; Al, M.J.; Hop, W.C.; Rutten-van Mölken, M.P. Real-life compliance and persistence among users of subcutaneous and sublingual allergen immunotherapy. J. Allergy Clin. Immunol. 2013, 132, 353-360.e2. [CrossRef]

51. Durham, S.R.; Penagos, M. Sublingual or subcutaneous immunotherapy for allergic rhinitis? J. Allergy Clin. Immunol. 2016, 137, 339-349.e10. [CrossRef] [PubMed]

52. Bergmann, K.C.; Demoly, P.; Worm, M.; Fokkens, W.J.; Carrillo, T.; Tabar, A.I.; Nguyen, H.; Montagut, A.; Zeldin, R.K. Efficacy and safety of sublingual tablets of house dust mite allergen extracts in adults with allergic rhinitis. J. Allergy Clin. Immunol. 2014, 133, 1608-1614.e6. [CrossRef] [PubMed]

53. Mosbech, H.; Canonica, G.W.; Backer, V.; de Blay, F.; Klimek, L.; Broge, L.; Ljørring, C. SQ house dust mite sublingually administered immunotherapy tablet (ALK) improves allergic rhinitis in patients with house dust mite allergic asthma and rhinitis symptoms. Ann. Allergy Asthma Immunol. 2015, 114, 134-140. [CrossRef] [PubMed] 
54. Demoly, P.; Emminger, W.; Rehm, D.; Backer, V.; Tommerup, L.; Kleine-Tebbe, J. Effective treatment of house dust mite-induced allergic rhinitis with 2 doses of the SQ HDM SLIT-tablet: Results from a randomized, double-blind, placebo-controlled phase III trial. J. Allergy Clin. Immunol. 2016, 137, 444-451.e8. [CrossRef]

55. Maloney, J.; Bernstein, D.I.; Nelson, H.; Creticos, P.; Hébert, J.; Noonan, M.; Skoner, D.; Zhou, Y.; Kaur, A.; Nolte, H. Efficacy and safety of grass sublingual immunotherapy tablet, MK-7243: A large randomized controlled trial. Ann. Allergy Asthma Immunol. 2014, 112, 146-153.e2.

56. Nelson, H.; Cartier, S.; Allen-Ramey, F.; Lawton, S.; Calderon, M.A. Network metaanalysis shows commercialized subcutaneous and sublingual grass products have comparable efficacy. J. Allergy Clin. Immunol. Pract. 2015, 3, 256-266.e3. [CrossRef]

57. Jutel, M.; Agache, I.; Bonini, S.; Burks, A.W.; Calderon, M.; Canonica, W.; Cox, L.; Demoly, P.; Frew, A.J; O’Hehir, R.; et al. International Consensus on allergen Immunotherapy II: Mechanisms, standardization, and pharmacoeconomics. J. Allergy Clin. Immunol. 2016, 137, 358-368.

58. Matsuda, M.; Terada, T.; Tsujimoto, N.; Morie, Y.; Ishida, T.; Takahashi, H.; Hamaguchi, J.; Tabuchi, Y.; Doi, K.; Noro, K.; et al. Regulatory $\mathrm{T}$ and $\mathrm{B}$ cells in peripheral blood of subcutaneous immunotherapy-treated Japanese cedar pollinosis patients. Immunotherapy 2019, 11, 473-482. [CrossRef]

59. Terada, T.; Matsuda, M.; Inaba, M.; Hamaguchi, J.; Takemoto, N.; Kikuoka, Y.; Inaka, Y.; Sakae, H.; Hashimoto, K.; Shimora, H.; et al. Sublingual immunotherapy for 4 years increased the number of Foxp3+ Treg cells, which correlated with clinical effects. Inflamm. Res. 2021, 70, 581-589. [CrossRef]

60. Malbec, O.; Fong, D.C.; Turner, M.; Tybulewicz, V.L.; Cambier, J.C.; Fridman, W.H.; Daëron, M. Fc epsilon receptor I-associated lyn-dependent phosphorylation of FC receptor IIB during negative regulation of mast cell activation. J. Immunol. 1998, 160, 1647-1658.

61. Fong, D.C.; Malbec, O.; Arock, M.; Cambier, J.C.; Fridman, W.H.; Daëron, M. Selective in vivo recruitment of the phosphatidylinositol phosphatase SHIP by phosphorylated Fc gamma RIIB during negative regulation of IgE-dependent mouse mast cell activation. Immunol. Lett. 1996, 54, 83-91. [CrossRef]

62. Ott, V.L.; Cambier, J.C. Activating and inhibitory signaling in mast cells: New opportunities for therapeutic intervention? J. Allergy Clin. Immunol. 2000, 106, 429-440. [CrossRef] [PubMed]

63. Ono, M.; Bolland, S.; Tempst, P.; Ravetch, J.V. Role of the inositol phosphatase SHIP in negative regulation of the immune system by the receptor Fc (gamma)RIIB. Nature 1996, 383, 263-266. [CrossRef] [PubMed]

64. Terada, T.; Zhang, K.; Belperio, J.; Londhe, V.; Saxon, A. A chimeric human-cat Fcgamma-Fel d1 fusion protein inhibits systemic, pulmonary, and cutaneous allergic reactivity to intratracheal challenge in mice sensitized to Fel d1, the major cat allergen. Clin. Immunol. 2006, 120, 45-56. [CrossRef] [PubMed]

65. Zhu, D.; Kepley, C.L.; Zhang, K.; Terada, T.; Yamada, T.; Saxon, A. A chimeric human-cat fusion protein blocks cat-induced allergy. Nat. Med. 2005, 11, 446-449. [CrossRef]

66. Lao-Araya, M.; Steveling, E.; Scadding, G.W.; Durham, S.R.; Shamji, M.H. Seasonal increases in peripheral innate lymphoid type 2 cells are inhibited by subcutaneous grass pollen immunotherapy. J. Allergy Clin. Immunol. 2014, 134, 1193-1195.e4. [CrossRef]

67. Jutel, M.; Akdis, M.; Budak, F.; Aebischer-Casaulta, C.; Wrzyszcz, M.; Blaser, K.; Akdis, C.A. IL-10 and TGF-beta cooperate in the regulatory $\mathrm{T}$ cell response to mucosal allergens in normal immunity and specific immunotherapy. Eur. J. Immunol. 2003, 33, 1205-1214. [CrossRef]

68. Ciprandi, G.; Cirillo, I.; Fenoglio, D.; Marseglia, G.; Tosca, M.A. Sublingual immunotherapy induces spirometric improvement associated with IL-10 production: Preliminary reports. Int. Immunopharmacol. 2006, 6, 1370-1373. [CrossRef]

69. Crimi, E.; Voltolini, S.; Troise, C.; Gianiorio, P.; Crimi, P.; Brusasco, V.; Negrini, A.C. Local immunotherapy with Dermatophagoides extract in asthma. J. Allergy Clin. Immunol. 1991, 87, 721-728. [CrossRef]

70. Tari, M.G.; Mancino, M.; Monti, G. Immunotherapy by inhalation of allergen in powder in house dust allergic asthma-A double-blind study. J. Investig. Allergol. Clin. Immunol. 1992, 2, 59-67.

71. Valovirta, E.; Passalacqua, G.; Canonica, W.G. Non-injection routes for immunotherapy of allergic diseases. Clin. Allergy Immunol. 2004, 18, 607-623. [PubMed]

72. Canonica, G.W.; Passalacqua, G. Noninjection routes for immunotherapy. J. Allergy Clin. Immunol. 2003, 111, 437-448. [CrossRef] [PubMed]

73. Wilson, D.R.; Lima, M.T.; Durham, S.R. Sublingual immunotherapy for allergic rhinitis: Systematic review and meta analysis. Allergy 2005, 60, 4-12. [CrossRef] [PubMed] 